\title{
Assessment of water quality of the Tisa river (Vojvodina, North Serbia) for ten year period using Serbian Water Quality Index (SWQI)
}

\author{
Igor Leščešen ${ }^{A}$, Milana Pantelić ${ }^{B}$, Dragan Dolinaj ${ }^{B}$, Tin LukićC $^{\circ}$ \\ Received: June 15, 2014 | Revised: September 21, 2014 | Accepted: November 10, 2014
}

\begin{abstract}
The WQI method is most frequently used in expert and scientific research and basically it provides a mechanism for cumulative representation, numeric expression and defining a certain level of water quality. This paper aims to assess water quality of the Tisa River in Vojvodina (North Serbia) for the 20032012 period. Serbian Water Quality Index (SWQI) was used for assessment of the river water quality. WQI is expressed as a single value ranging from o to 100 (best quality) derived from numerous physical, chemical, biological and microbiological parameters. The results of SWQI for the Tisa River were mainly rated as good. Also, in this study it is noticed a clear decrease in water quality during warmer period of the year. Also, this study shows that water quality along the Tisa River decreases slightly but steadily downstream, from Martonoš to Titel station and all along the length of the river provides values that according to SWQI descriptive quality indicator has been defined as good (72-83). The main problem of SWQI used in this paper is that it does not involve parameters of heavy metals concentration.
\end{abstract}

Key words: Tisa River, North Serbia, Vojvodina, water quality

\section{Introduction}

Only healthy and unpolluted aquatic ecosystem is an integral part of life and is an essential resource for meeting the needs of many. Therefore, water protection becomes imperative, the key for the sustainable development in order to preserve the quality of the environment, social welfare and economic security, areas that are essentially intertwined and dependent. On the other hand, pressure on aquatic ecosystems are extremely large, and the regenerative ability of aquatic ecosystems is limited (Belić, et al., 2004, 2005; Josimov-Dunđerski, Belić, 2005a). The most common cause of degradation of the quality of aquatic ecosystems is polluted water. These are waters that have changed their original composition of the release of harmful substances, whose presence caus- es a change in the physical, chemical, biological or bacteriological water conditions to an extent that may limit or prevent its use. Water quality is variable in time and space. Therefore, it is extremely important monitoring and knowledge of the current state of water quality (Josimov-Dunđerski, Belić, 2005b). Water Quality index attempts to provide a mechanism for presenting a cumulatively derived numerical expression defining certain level of water quality (Miller, et al., 1986), and is useful for comparative purposes and when general questions are addressed (Hallock, 2002; Bordalo, et al., 2006). In this study, the water quality status, as well as the spatial and temporal trends over ten year period (from 20032012) is assessed on three different locations along the Tisa River in Vojvodina (North Serbia).

\footnotetext{
A Association of young researches "Branislav Bukurov" Faculty of Science, University of Novi Sad, Trg Dositeja Obradovića 3, 21000 Novi Sad, Serbia; igorlescesen@yahoo.com

B Climatology and Hidrology Research Centre, Faculty of Science, University of Novi Sad, Trg Dositeja Obradovića 3, 21000 Novi Sad, Serbia;

c Department of Geography, Tourism and Hotel Management, Faculty of Science, University of Novi Sad, Trg Dositeja Obradovića 3, 21000 Novi Sad, Serbia
} 


\section{Materials and methods}

\section{Sampling area}

Basin of the Tisa River occupies about $157,220 \mathrm{~km}^{2}$ with a length of $966 \mathrm{~km}$, and it is the largest tributary of the Danube River. Basin of this river lies in the territories of five countries: Romania (47\%), Hungary (29\%), Slovakia (10\%), Ukraine (8\%) and Serbia (6\%). Regulation works which were conducted during the XIX and XX century primarily in the middle and lower parts of the Tisa River is shortened by as much as $453 \mathrm{~km}$, or from the former $1419 \mathrm{~km}$ to the current 966 $\mathrm{km}$ (Pavić et al., 2009). Serbian part is $164 \mathrm{~km}$ long. It enters Serbia south of Hungarian city of Szeged and flows into Danube River near the town of Slankamen. Tisa is one of the largest and economically and environmentally most important watercourses in Serbia. In fact, thanks to its favorable location and good navigational characteristics it has a potentially to be far more frequent passenger-cargo and nautical tourism traffic route (Pavić, et al., 2004; 2009).

In determining the water quality of the Tisa River in Serbia, monthly data obtained from three stations were used. These three stations are Martonoš which is located at 155 river kilometre, Novi Bečej at $65.0 \mathrm{~km}$ and Titel at $9.8 \mathrm{~km}$.

\section{Data and Methods}

Database of Republic Hydrometeorological Service for the period 2003 - 2012 (RHMS, 2012) was used to present the existing state of water quality of the Tisa River. Parameters of physical, chemical, biological and microbiological water quality were measured at the three control points on Tisa River: Martonoš, Novi Bečej, and Titel during period from 2003 to 2012.

Water Quality Index (WQI) represents one of the most reliable indicator of waterflow pollution (Córdoba, et al., 2010; Srebotnjak, et al., 2011). The WQI method is most frequently used in expert and scientific research and basically it provides a mechanism for cummulative representation, numeric expression and defining a certain level of water quality (Miller, et al., 1986; Hambright, et al., 2000; Jonnalagadda, Mhere, 2001). In this paper we used Serbian Water Quality Index (SWQI) for description of the water quality. This system of surface waterbodies quality description represents the way of quality estimation for certain parameters group, where earlier researches and studies show that this method ensures general overwiev of surface water quality at cer-

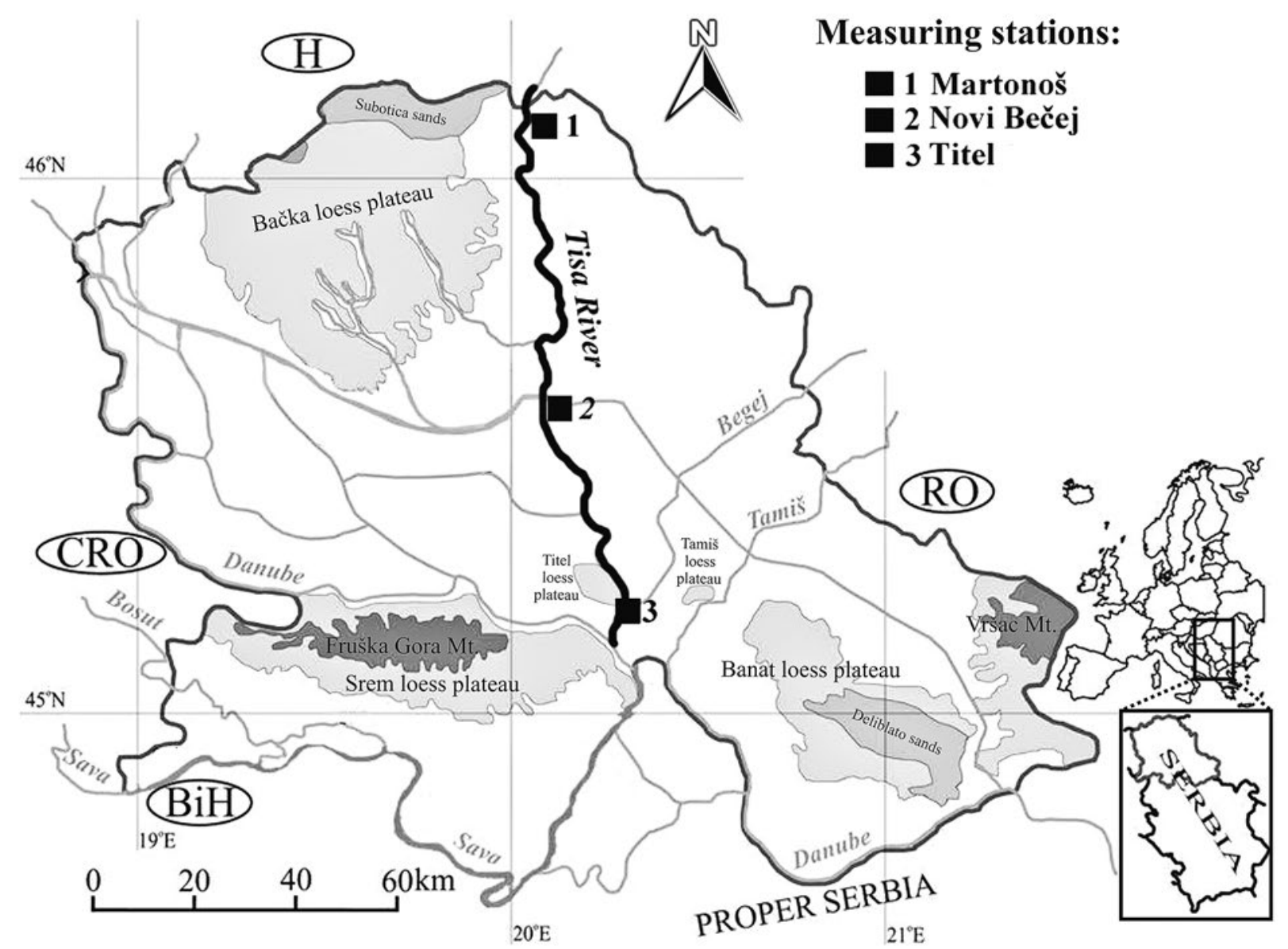

Figure 1. Geographical location of the research area and measuring stations at the Tisa River 
tain place (Veljković, 200o; Veljković, 2001; Veljković, 2003; Đurašković, Vujović, 2004; Đurašković, Tomić, 2009; Pantelić, et al., 2012; Leščešen, et al., 2013; Bjelajac et al., 2013). The essence of the SWQI is that the ten chosen parametres (oxygen saturation, $\mathrm{BOD}_{5}$, ammonium ion, $\mathrm{pH}$ value, total nitrogen, orthophosphates, suspended matter, temperature, electroconductivity and coliform bacteria) by means of their quality (qi) represent the characteristics of surface waters reducing them to one index number. The impact of each of the ten chosen parameters on the overall water quality does not have the same relative importance which is the reason why each of them got its own weight (wi) and a number of points per share in endangering quality. By adding up the products (qi $\mathrm{x}$ wi) the index 100 is gained as the ideal sum of the weight of all the parameters (Oregon Water Quality Index Summary Report, 1996-2005). Index points from o to 100 will be assigned to particular waterbody according to the points assigned to particular parameters (Pantelić et al., 2012; Leščešen et al., 2013; Bjelajac et al., 2013). Formula used for SWQI calculation is:

$$
\begin{aligned}
\text { SWQI }= & 0.18 \% \mathrm{O}_{2}+0.15 \mathrm{BPK}_{5}+0.12 \mathrm{NO}_{4}+0.09 \mathrm{pH}+ \\
& 0.08 \mathrm{~N}+0.08 \mathrm{PO}_{4}+0.07 \mathrm{SM}+0.05 \mathrm{t}+0.06 \mu \mathrm{S} \\
& +0.12 \mathrm{MPN}
\end{aligned}
$$

Table 1. Classification of water quality on the basis of Water Quality Index

\begin{tabular}{|l|l|}
\hline WQI value & Descriptive indicator \\
\hline $0-38$ & very bad \\
\hline $39-71$ & bad \\
\hline $72-83$ & good \\
\hline $84-89$ & very good \\
\hline $90-100$ & excellent \\
\hline
\end{tabular}

Source: Veljkovic, $2000 \mathrm{~b}$

Main limitation for SWQI is relative small number of parameters. Used parameters provide information about organic loading, but not about heavy metal pol- lution. Also, SWQI can be calculated even in a case of missing some values. Since there is no single, universal parameter that properly describes surface waterquality, investigators typically use several indicators related to sanitary quality, ability to sustain aquatic life, ecosystem productivity and aesthetics (Pharino, 2007).

\section{Results}

Average values of ten water quality parameters for all three control points are presented in table 1. Monthly values of these parameters were used to calculate SWQI for the Tisa River. Temperature varies from minimum $13.7^{\circ} \mathrm{C}$ at Martonoš station to $14.6^{\circ} \mathrm{C}$ at Titel station. The water acidity measures from remains constant downstream from Martonoš till Novi Bečej station and it is 7.9, slightly lower value was measured at Title station, 7.8. Highest average conductivity was recorded on Martonoš and Novi Bečej station $453.86 \mu \mathrm{S} \mathrm{cm}-1$. Average Oxygen saturation for research period is $83.80 \%$ with highest value measured at Martonoš station (88.32\%) and lowest value at Novi Bečej station (81.25\%). Biochemical oxygen demand is used as a measure of organic wasteload strength, and on the Tisa River, it varies from lowest $2.02 \mathrm{mg} / \mathrm{l}$ on Martonoš station till $2.33 \mathrm{mg} / \mathrm{l}$ on Novi Bečej station. Another important indicator of water quality is the amount of solids in the water column - both dissolved (filterable) solids and not dissolved (suspended) solids (Pharino, 2007). Suspended solids show progressive decrease from Martonoš station $(56.97 \mathrm{mg} / \mathrm{l})$ till Novi Bečej station $(53.42 \mathrm{mg} / \mathrm{l})$. On Titel station higher values are measured $61.91 \mathrm{mg} / \mathrm{l}$. Total oxidiesed nitrogen values for the Tisa River vary from $1.12 \mathrm{mg} / \mathrm{l}$ at Titel station, till its highest value at Martonoš station 1.21 $\mathrm{mg} / \mathrm{l}$. Highest values of orthophospates during 2003 - 2012 period is measured at Novi Bečej and Titel stations $(0.06 \mathrm{mg} / \mathrm{l})$. Amonium values vary from the lowest values measured at Martonoš station $(0.15 \mathrm{mg} / \mathrm{l})$ to its highest value measured at Titel station $(0,22 \mathrm{mg} / \mathrm{l})$. Values of coliform bacteria decrease continuously from Martonoš (11443 n/l) to Titel station (5456 n/l).

\begin{tabular}{|c|c|c|c|c|c|c|c|c|c|c|}
\hline Station & 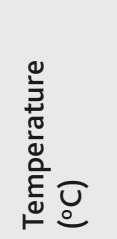 & I & 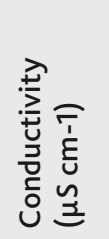 & 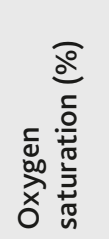 & 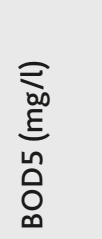 & 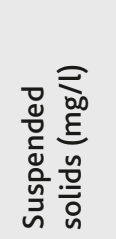 & 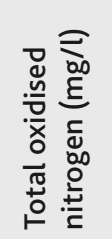 & 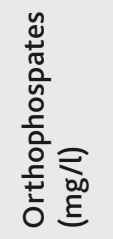 & 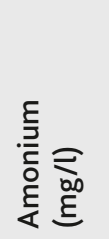 & 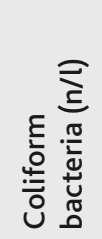 \\
\hline Martonoš & 13.7 & 7.9 & 453.86 & 88.32 & 2.02 & 56.97 & 1.21 & 0.05 & 0.15 & 11443 \\
\hline Novi Bečej & 14.4 & 7.9 & 453.86 & 81.25 & 2.33 & 53.42 & 1.15 & 0.06 & 0.17 & 8046 \\
\hline Titel & 14.6 & 7.8 & 441.67 & 81.82 & 2.09 & 61.91 & 1.12 & 0.06 & 0.22 & 5456 \\
\hline
\end{tabular}

Table 2. Averaged values for ten water parameters included for calculation of SWQI for the Tisa River covered by this study: 2003-2012 period. 
Table 3. Monthly values of SWQI for Martonoš station

\begin{tabular}{|c|c|c|c|c|c|c|c|c|c|c|}
\hline SWQI & 2003 & 2004 & 2005 & 2006 & 2007 & 2008 & 2009 & 2010 & 2011 & 2012 \\
\hline I & 72 & 74 & 82 & 76 & 80 & 80 & 78 & 81 & 84 & 84 \\
\hline II & $x$ & 69 & 78 & 69 & 86 & 80 & 81 & 75 & 83 & 84 \\
\hline III & 69 & 80 & 76 & 68 & 83 & 81 & 83 & 82 & 83 & 86 \\
\hline IV & 78 & 74 & 78 & 77 & 88 & 85 & 88 & 80 & 79 & 86 \\
\hline V & 85 & 85 & 81 & 85 & 83 & 84 & 85 & 76 & 87 & 72 \\
\hline $\mathrm{VI}$ & 68 & 76 & 68 & 75 & 81 & 80 & 86 & 70 & 81 & 84 \\
\hline VII & 75 & 76 & 70 & 69 & 82 & 82 & 79 & 67 & 82 & 83 \\
\hline VIII & 51 & 72 & 71 & 72 & 81 & 83 & 85 & 75 & 84 & 86 \\
\hline IX & 80 & 82 & 78 & 76 & 80 & 79 & 88 & 79 & 80 & 85 \\
\hline$x$ & 83 & 86 & 80 & 81 & 84 & 86 & 83 & 86 & 87 & 84 \\
\hline$X I$ & 85 & 78 & 91 & 75 & 78 & 84 & 82 & 81 & 90 & 83 \\
\hline XII & 77 & 78 & 74 & 83 & 80 & 77 & 82 & $x$ & 85 & $x$ \\
\hline Average & 75 & 78 & 77 & 76 & 82 & 82 & 83 & 77 & 84 & 83 \\
\hline
\end{tabular}

SWQI was calculated 117 times throughout ten year period for Martonoš station (Table 2 ) and ranged from average value of 75 in 2003 to 84 in 2011. According to the obtained results, water quality of the Tisa River at Martonoš station could be classified as good $(72-83)$. Lowest monthly value was observed during August of 2003, when index value was 51 (poor), while the highest monthly value was observed in November 2011, 90 (excellent). Missing monthly data in tables 2, 3, and 4 is marked with $\mathrm{X}$.

SWQI was calculated 112 times for Novi Bečej station (Table 3) and ranged on average from 70 in 2003 to 82 in 2008, 2009 and 2012. Generally, water quality of the Tisa River at Novi Bečej station can be classified as poor (39 $-71)$ in 2003 and good $(72-83)$ during last nine years of investigated period (2004 - 2012). Lowest monthly value was observed during July when index value was 49 (poor). Highest index value was observed during July of 2008 and March of 2009, both 91 (excellent).
For Titel station SWQI was calculated 112 times on monthly basis for ten years. Its values ranged from lowest 71 measured in 2003 and 2005 to 83 measured in 2012. The monthly results are represented in table 4. Water quality of the Tisa River at Titel station can be classified as poor in 2003 and $2005(39-71)$ and good during the rest of the investigated period $(72-83)$.

\section{Discussion}

The water quality status, spatial and temporal trends along Tisa River were assessed through the application of ten parameter SWQI, to a ten year public database of environmental data. In the case of the Tisa River it should be stated that the index is not adopted to a specific use, such as bathing water or fish spawning, but rather producing a general index to determine the overall water quality. According to the SWQI, water quality of the Tisa River in Serbia during the peri-

Table 4. Monthly values of SWQI for Novi Bečej station

\begin{tabular}{|c|c|c|c|c|c|c|c|c|c|c|}
\hline SWQI & 2003 & 2004 & 2005 & 2006 & 2007 & 2008 & 2009 & 2010 & 2011 & 2012 \\
\hline I & $x$ & 76 & 80 & 77 & 81 & 74 & 85 & 81 & 83 & 85 \\
\hline II & $x$ & 77 & 79 & 73 & 82 & 82 & 82 & 75 & 80 & 82 \\
\hline III & 75 & 77 & 74 & 77 & 85 & 81 & 91 & 81 & 82 & 74 \\
\hline IV & 75 & 69 & 77 & 77 & 80 & 86 & 80 & 80 & 89 & 86 \\
\hline V & 83 & 77 & 67 & 75 & 84 & 83 & 82 & 75 & 74 & 83 \\
\hline VI & 58 & 82 & 72 & 74 & 70 & 76 & 73 & 76 & 73 & 85 \\
\hline VII & 49 & 74 & 73 & 76 & 81 & 91 & 77 & 66 & 75 & 75 \\
\hline VIII & 58 & 73 & 73 & 74 & 61 & 82 & 78 & 69 & 83 & 71 \\
\hline IX & 64 & 76 & 74 & 70 & 52 & 85 & 82 & 78 & 80 & 82 \\
\hline$x$ & 83 & 81 & 73 & 72 & 81 & 85 & 83 & 84 & 85 & 85 \\
\hline$X I$ & 78 & 72 & $x$ & 70 & 85 & 83 & 86 & 85 & 83 & 84 \\
\hline XII & 78 & 73 & $x$ & $x$ & 82 & 79 & $x$ & $x$ & $x$ & 86 \\
\hline Average & 70 & 76 & 74 & 74 & 77 & 82 & 82 & 77 & 81 & 82 \\
\hline
\end{tabular}


Table 5. Monthly values of SWQI for Titel station

\begin{tabular}{|c|c|c|c|c|c|c|c|c|c|c|}
\hline SWQI & 2003 & 2004 & 2005 & 2006 & 2007 & 2008 & 2009 & 2010 & 2011 & 2012 \\
\hline I & $x$ & $x$ & 82 & 76 & 68 & 76 & 76 & 78 & 85 & 86 \\
\hline II & 69 & 70 & 58 & 65 & 69 & 83 & 70 & 75 & 80 & 86 \\
\hline III & $x$ & 78 & 78 & 76 & 83 & 80 & 72 & 84 & 80 & 86 \\
\hline IV & 74 & 74 & 76 & 74 & 82 & 84 & 86 & 85 & $x$ & 85 \\
\hline V & 75 & 75 & 73 & 75 & 74 & 81 & 68 & 75 & $x$ & 76 \\
\hline $\mathrm{VI}$ & 70 & 86 & 75 & 72 & 81 & 75 & 79 & 68 & 66 & 75 \\
\hline VII & 60 & 76 & 72 & 76 & 85 & 80 & 78 & 67 & 77 & 81 \\
\hline VIII & 69 & 67 & 60 & 74 & 73 & 72 & 69 & 75 & 80 & 82 \\
\hline IX & 70 & 75 & 78 & 79 & 68 & 73 & 78 & 83 & 82 & 86 \\
\hline$x$ & 70 & 80 & 63 & 72 & 76 & 81 & 80 & $x$ & 87 & 86 \\
\hline$X I$ & 80 & 80 & 66 & 76 & 77 & 86 & 67 & $x$ & 82 & 85 \\
\hline XII & 76 & 74 & 70 & 78 & 76 & 84 & 77 & $x$ & 80 & $X$ \\
\hline Average & 71 & 76 & 71 & 74 & 76 & 80 & 75 & 77 & 80 & 83 \\
\hline
\end{tabular}

od 2003 - 2012, was assessed as good (average 78). Values of SWQI for research period fluctuate from 70 in 2003 (Novi Bečej) to 84 in 2011 (Martonoš). First value is classified, according to SWQI descriptive quality indicator as poor $(39-71)$, and the second value can is classified as very good. However, these results should be accepted as questionable, because SWQI gives information about organic loading, but not about heavy metals pollution. Along $164 \mathrm{~km}$ stretch of the Serbian part of the Tisa River, the water quality has dropped modestly, but continuously downstream. The control point Titel had the lowest mean value SWQI (76). Largest mean value is recorded at the measuring station Martonoš (8o).

Temperature can also have influence on water quality. If water temperature in river is higher, there is intensive biological activity and dissolved oxygen concentration lessens (Sanchez, 2007; Bjelajac, et al., 2013). Seasonal variance in water quality was observed and some patterns were noticed on all four stations. Lowest values o SWQI were observed at all stations during June, July, and August. On average, value of SWQI on all three stations, for June and July during 2003 - 2012 is 75, and in August 73. Values for months June, July and August are according to SWQI nomenclature classified as good. Values of SWQI are, on average, highest on Martonoš station during these months, and decrease of SWQI is constant downstream. On all three stations values of SWQI are classified as good during entire investigated period, except already mentioned year of 2003 on Novi Bečej (70) station and 2003 and 2005 on Titel station (71). When we analyzed the values of SWQI for four seasons, highest values were obtained for autumn (80) and spring (79), little lower value were obtained for winter $(78)$ and the lowest value of SWQI on the Tisa River is measured during summer (75). From these data, we can conclude that water quality of the Tisa River is worse in warmer period of the year with average index value of 77 , while the average value for the cold period of the year is 79. Numerous researches stated the same trend, e.g. Suquia River, Argentina (Pesce \& Wunderlin, 2000), Odzi River, Zimbabwe (Jonnalagadda, Mhere, 2001), Bangpakong River, Thailand (Bordalo, et al., 2001), San Vicente Bay, Chile (Rudolf, et al., 2002), Pampa Murillo, Mexico (Hernández-Romero, et al., 2004), Veliki Bački kanal, Serbia (Pantelić, et al., 2012), Drina River (Levščešen, et al., 2013) Sava River (Bjelajac, et al., 2013).

\section{Conclusion}

This study strives to highlight the importance of applying a WQI that reflects the collective influence of various criteria and allows easy interpretation of data from monitoring networks. Additionally, this study shows that water quality along the Tisa River decreases slightly downstream, but it still provides values that according to SWQI descriptive quality indicators have been defined as good $(72-83)$. Exceptions are index values measured in 2003 on Novi Bečej station (70) and in 2003 and 2005 on Titel station (71), values for this years has been definite as poor $(39-71)$. Based on the results of the study that analysed the impact of ten parameters measured on three control points during 2003 - 2012 period on water quality of the Tisa River, it can be concluded that natural factors, most of all, water temperature affects changes in water quality throughout the ten year investigated period. In recent years the anthropogenic impact on the quality of the Tisa River is far more intensive. Therefore, this study has established that natural factors may affect the reduction or increase of Water Quality Index throughout the investigated period up to a certain extent. 


\section{References}

Belić, A., Josimov-Dunđerski, J., Popović, T. 2004. Workload of some stocks DKM HS DTD wastewater and power of self-purification, Thematic Proceedings "Agriculture modification of droughts and floods", p. 20-25, Faculty of Agriculture, Novi Sad, Department of Planning water.

Belić, A., Josimov-Dunđerski, J., Stojanović, T. 2005. Pollution Migration and Transformation along Lateral Canals in Vojvodina, Proceedings on CD from the 7 th World Congress on Recovery, Recycling and Re-integration (Ro5), and Abstracts of Paper, pp. 299, Beijing, China.

Bjelajac, D., Leščešen, I., Micić, T., Pantelić, M. 2013. Estimation of water quality of Sava River (Vojvodina, Serbia) in the period 2004-2011using Serbian Water Quality Index (SWQI), Geographica Pannonica 17 (4) 91-97.

Bordalo A. A., Teixeira, R., William, J. W. 2006. A Water Quality Index Applied to an International Shared River Basin: The case study of the Duro River. Environ Manage 38:910-920.

Bordalo, A.A., Nilsumranchi, W., Chalermwat, K. 2001. Water quality and uses of the Bangpakong River (Eastern Thailand). Water Research 35, 3535-3642.

Córdoba, E.B., Martínez, A.C., Ferrer, E.V. 2010. Water quality indicators: Comparison of a probabilistic index and a general quality index. The case of the Confederación Hidrográfica del Júcar (Spain). Ecological Indicators 10 (5), 1049-1054.

Đurasković, P., Vujović, A. 2004. Supplement to the Skadar Lake Water Eutrophication Study, Conference on Water Observation and Information System for Decision Support, Ohrid, Macedonia.

Đurašković, P. N., Tomić, N. 2009. Skadar Lake Water Quality by WQI Method.Conference "Zastitavoda o9", Zlatibor, Serbia. [In Serbian]

Hallock, O. 2002. A water quality index for ecology's stream monitoring program. Washington State Department of Ecology, Olympia WA. Publication No 0203052, 23 pp.

Hernández-Romero, A.H., Tovilla-Hernández, C., Malo, E.A., Bello-Mendoza, R. 2004. Water quality and presence of pesticides in a tropical coastal wetland in southern Mexico.Marine Pollution Bulletin 48, 1130-1141.

Josimov-Dunđerski, J., Belić, A. 2005a. Self-cleaning power of the recipient - lateral canals drainage system Žitište, Modern, Br. 1, Vol. 28, (2004), 97-103 pp., Faculty of Agriculture, Novi Sad.

Josimov-Dunđerski J., Belić A. 2005b. Water quality lateral canals drainage system Žitište VI of the International Conference organized by EKO 05, Monograph Environmental suburban area and villages, the Ecological Movement of Novi Sad, Volume I 141-146 pp., Novi Sad.

Leščešen, I., Kotrla, S., Otašević, K., Pantelić, M., Josimov, A., Čeperković, M., 2013. Assesment of Water Quality Parametres of Drina River (West Serbia) in the Period 2004-2011. European Researcher $61(10-2)$.

Miller, W.W., Joung, H.M., Mahannah, C.N. 1986. Identification of water quality differences in $\mathrm{Ne}$ vada through index application. Journal of Environmental Quality 15, 265-272.

Oregon Water Quality Index Summary Report, Water Years 1996-2005, Curtis Cude, DEQ Laboratory Division, Water Quality Monitoring Section, USA.

Pantelić, M., Dolinaj, D., Savić, S., Stojanović, V., Nađ, I. 2012. Statistical Analysis of water quality parameters of Veliki Bački Canal (Vojvodina, Serbia) in period 2000-2009. Carpathian Journal of Earth and Environmental Sciences 7 (2), 255-264.

Pavić, D., Dolinaj, D., Dragićević, S. 2009. Thermal regime and the regime of water ice on the Tisa River, Tisa river in Serbia, Collection of the Papers vol. LVII, 35-46.

Pavić, D., Mesaroš, M., Živković, N. 2006. Pollution and water quality of the river Tisa in Serbia, Collection of the Papers vol. LVIII, 47-62.

Pesce, S.F., Wunderlin, D.A. 200o. Use of water quality indices to verify the impact of Cordoba City (Argentina) on Suquia River. Water Research 34, 29152926.

Rudolf, A., Ahumada, R., Pérez, C. 2002. Dissolved oxygen content as an index of water quality in San Vicente Bay, Chile (36 degrees, 450S). Environmental Monitoring and Assessment 78, 89-100.

Srebotnjak, T., Carr, G., de Sherbinin, A., Rickwood, C. 2011. A global Water Quality Index and hot-deck imputation of missing data. Ecological Indicators 17, 108-119.

Veljkovic N., 2003. Indicator of sustainable development of Southern Morava river basin Ecoagglomeration Development Index, Environmental and Public Health Recovery and Protection, UCIS, University of Pittsburgh.

Veljković, N. 2000. Determinig water quality index of the Southern Morava basin by the application of WQI method. Waters Protection 2000, Yugoslav Society for Waters Protection, Belgrade. [In Serbian]

Veljković, N. 2001. Measuring indicators of sustainable water development for agglomerations in theSouthMorava basin. 11th Stockholm Water Symposium, Abstract Volume: Building Bridges Through Dialogue, Stockholm, Sweden.

Jonnalagadda, S. B., Mhere G. 2001. Water quality of the Odzi River in the Eastern highlands of Zimbabwe.Water Research 35, 2371-2376. 